\title{
Assessment of Staff Retention in Private Universities in Ghana: A Study of the Perez University College, Winneba
}

\author{
Peter Kwegyir-Aggrey ${ }^{1}$
}

Research Fellow Centre for Educational Policy Studies Institute for Educational Research and Innovation Studies (IERIS), University of Education, Winneba

\begin{abstract}
Staff turnover especially among lecturers in private universities is high due to poor and disappointing conditions of service. This negatively affects effective teaching, learning and research. The purpose of the study was to examine the causes of staff turnover in private universities, using the Perez University College in Winneba as a case study. The study employed the descriptive survey design to collect data from forty (40) lecturers and twenty (20) administrative staff. The convenience sampling technique was therefore used to obtain the sample size of 60 respondents. Questionnaire and interview guides were used to collect data. The study revealed that lecturers and top administrators were poorly paid. There was low research output among lecturers in private universities. Libraries lack current publications and ICT connectivity to support teaching, learning and research. The study recommended the improvement in the conditions of service of staff. It also recommended the establishment of a research fund to motivate lecturers to increase research output as well as ICT connectivity to support effective teaching, learning and research in private universities in Ghana.
\end{abstract}

Keywords: Staff retention, Compensation packages, Academics, Research expertise, Performance appraisal, Employee morale, Lecturer attrition, Research output

\section{Contents}

1. Introduction .

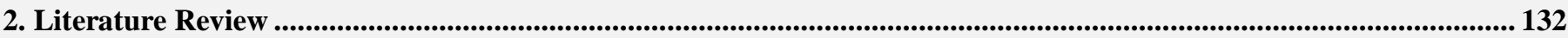

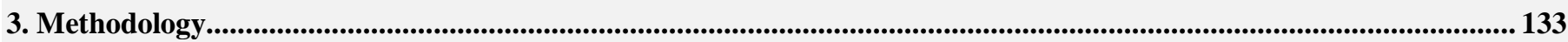

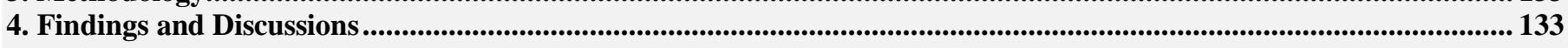

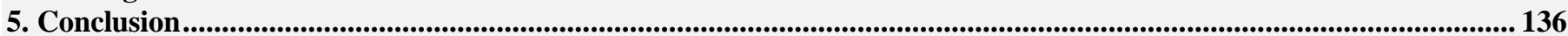

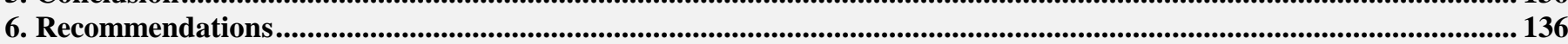

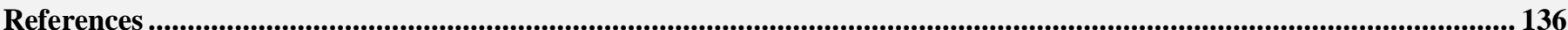

Citation | Peter Kwegyir-Aggrey (2016). Assessment of Staff Retention in Private Universities in Ghana: A Study of the Perez University College, Winneba. Journal of Education and e-Learning Research, 3(4): 130-137.

DOI:

$\operatorname{ISSN}(\mathbf{E})$ :

$\operatorname{ISSN}(\mathbf{P})$ :

Licensed:

Funding:

10.20448/journal.509/2016.3.4/509.4.130.137 Crossref

$2518-0169$
This work

Competing Interests:

This work is licensed under a Creative Commons Attribution 3.0 License $(\mathrm{cc}) \mathbf{E}$

Transparency:

This study received no specific financial support.

The author declares that there are no conflicts of interests regarding the publication of this paper

History:

The author confirms that the manuscript is an honest, accurate, and transparent account of the study was reported; that no vital features of the study have been omitted; and that any discrepancies from the study as planned have been explained.

Ethical: Received: 8 October 2016/ Revised: 19 November 2016/ Accepted: 23 November 2016/ Published: 26 November 2016

Publisher: 


\section{Introduction}

\subsection{Background of the Study}

Ghana's educational sector has experienced a massive transformation from the basic to the tertiary level. Until recently, tertiary education in Ghana was provided by the state and was provided in public universities, polytechnics as well as other tertiary educational institutions (www.nab.gov.gh). Besides, the public tertiary institutions, there are also several private universities such as the Perez University College at Pomadze near Winneba in the Central Region of Ghana. Thus, tertiary education provision in Ghana is liberalized and has therefore become competitive. Adu (2009) opines that one reason for the liberalization of tertiary education in Ghana is to reduce pressure on the public universities in the provision of quality tertiary education.

In the light of the healthy and keen competition, both private and public universities are to recruit competent staff, provide effective compensation packages and appropriate structures to gain competitive advantage. Kidwell and Bennet (2014) assert that retention of talented staff promotes decision making capabilities, enhances quality of curriculum programmes based on best practices, improve academic services and reduces turnover costs. It is, therefore, vital for organizations to make informed decisions and develop effective retention practices that result in the reduction of employee turnover in private universities (Hillmer, 2004). It is widely accepted that employees are the backbone of every organization because they develop the organization. Their retention is, therefore, important to the success of the organization. University authorities need to develop effective strategies to develop and retain the best talented employees.

According to Coetzee and Rothman (2002) academics are essential to societal life because they educate the leaders of the society, conduct scientific research and advance knowledge. Shikha (2012) also added that academic institutions produce highly skilled and enlightened intellectual capital for the social transformation and economic development of a nation, and develop core business activities as well as research expertise to deliver quality learning experiences to students (Netswera, 2006). The people who make up an institution workforce are considered an asset just like its financial and material resources. This is because the global economy is becoming increasingly knowledge driven and intellectual capital is now considered as a critical human resource that makes an organization attain competitive advantage. Consequently, higher educational institutions need to reduce their employee turnover levels and increase employee retention level (Mankoe, 2007).

Generally, retaining the desirable employees is beneficial to an organization. It makes it gain competitive advantage and produces high morale among the workers. Stavrou-Costea (2005) asserts that an effective and efficient human resource management practices help improve retention of employees, thereby reducing employee turnover. As supported by Lee and Lee (2007) human resource management practices on business performance, namely training and development, teamwork, compensation/incentive, human resource planning, performance appraisal and employee security help improve institutional performance including employees' productivity.

\subsection{Statement of the Problem}

It is common to see lecturers and top administrative staff of private universities in Ghana leaving their job for public universities. In most cases, the migration is too frequent and alarming. Whilst some are of the view that private universities do not treat their staff well, others hold contrary view (Mankoe, 2007). When staff are not provided with good working conditions, proper salary/compensation packages, leave benefits etc, it demoralizes them and compels them to leave the organization. In addition, the absence of effective retention strategies such as education and training opportunities, retirement plans/packages, health and related benefits also induce staff to leave an organization (www.nab.gov.gh). Many private universities in Ghana have become vulnerable to losing their highly qualified academic and administrative staff to public universities and to few private universities that pay well. Martin and Roodt (2008) noted that educational institutions, especially private universities in order to enhance the retention level of their highly qualified lecturers, employee turnover has significant implication for academic institutions. They continue by saying that high rate of lecturer turnover has serious and costly human capital loss. It endangers the quality of teaching, learning and research capacities of private universities.

A survey conducted by the SAS Institute indicated that:

i. Loss of high performers in an organization is costly

ii. High level of employee turnover decreases the chances of innovation and

iii. That retention of high performers in academic institutions ultimately increases the chances of better informed research findings, technological advancement and overall economic growth.

Heathfield (2011) argues that retaining employees ensures customer satisfaction, increased product/service sales, increased worker confidence, effective succession planning and deeply embedded organizational knowledge and learning.

Perez University College is a private academic institution which has been experiencing human resource retention problems both at the instructional and administrative levels. For example, each year, not less than $65 \%$ lecturers leave the institution for employment elsewhere. In this regard, the study aims at examining the link between effective compensation system and employee retention in private universities, using the Perez University College as a case study.

\subsection{Purpose of the Study}

The purpose of the study was to examine how employee compensation package/system affects employee retention in private universities in Ghana with the Perez University College in focus.

\subsection{Objectives of the Study}

The following specific objectives guided the study:

1. To find out causes of staff turnover 
2. To identify compensation package for employees

3. To examine the influence of staff turnover on teaching, learning and research.

\subsection{Research Questions}

In search of answers to the research problem, the following questions guided the study.

1. What causes staff turnover in private universities in Ghana?

2. What constitutes compensation package for employees in private universities in Ghana?

3. How does staff turnover influence teaching, learning and research

\subsection{Significance of the Study}

Human resource is a vital component of the assets of an organization including the university - either private or public. This study is significant because it would investigate the causes of staff turnover, especially the lecturer category, and how the high rate of lecturer attrition in private university affects teaching, learning and research in these tertiary educational institutions in Ghana. The results of the study, it is believed, would assist management in private universities to develop effective and enhanced motivational packages to attract and retain highly qualified academic and administrative staff to ensure best practices in teaching, research and scholarship. Again, the study would be significant because it would help management of private universities to formulate policies and programmes towards appropriate staff development so that highly qualified academics could be home grown and retained. The findings of the study may also serve as a store of knowledge on the administration and management of private universities for further research and relevant policy development for private tertiary educational institutions in Ghana.

\section{Literature Review}

Human resource (HR) is a term used in organizations to refer to the workforce of an organization. It is also used to refer to a section of an organization responsible for managing the employees of that organization in terms of hiring, placement, training/education (ie staff development), benefits and compensation packages as well as firing $(\mathrm{Ng}, 2014)$. According to Byars and Rue (2006) human resource management is a system of activities and strategies that focus on successfully managing employees at all levels of an organization to achieve organizational goals.

Employees' retention refers to the ability of an organization to retain its staff. Employee turnover in an organization is a deep-seated issue that has not been fully resolved $(\mathrm{Ng}, 2014)$. This issue includes low staff morale, absence of a clear cut career path, lack of recognition, poor employee-manager relationships etc. Pay does not always induce staff turnover as is typically believed (Byars and Rue, 2006). Retention strategies strengthen the capacities of organizations to attract and retain their workforce. A strategic approach to employee retention may include adopting effective methods of engagements, safe and healthy workplaces and creating flexible work arrangements. Retention practices help create an inclusive and diverse workforce where barriers are reduced and individuals can carry out their duties in an acceptable manner (Afenyo, 2012).

Studies have shown that the organizational head has more power to reduce staff turnover. This is because the factors that drive employee satisfaction and commitment are largely within the manager's control (Buckingham and Coffman, 1999). Abelson and Baysinger (1984) opine that human resource management strategy should balance the cost of replacing the employee who leaves against the cost of retaining those who stay; since it is generally more expensive to replace highly productive employees than to replace weak performers (Cascio, 1982).

Turnover is said to be the rate of change in the working of an employee in an organization over a period of time. Human resource experts differentiate between instances of voluntary turnover initiated at the choice of the employee and those involuntary instances where the employee has no choice in their termination. Typically, the characteristics of employees who engage in involuntary turnover are no different from job stayers (Ganesan, 2010). Rossano (1985) also defines turnover as voluntary termination of participation in employment from an organization, excluding retirement or pressured voluntary withdrawal by an individual who receives monetary compensation from the organization. Turnover is considered as a bad sign for an organization as it involves considerable visible and hidden costs.

Allen (2006) states that much research on talent retention has centered on understanding the varied reasons behind employees' decisions to leave organization as well as the processes by which people make such choices. By understanding why people leave, organizations can also gain a better idea of why people stay and can learn how to influence these decisions. The theory of organizational equilibrium can shed valuable light on these matters. According to the theory, as indicated by Allen, an individual stays with an organization as long as the inducements it offers are equal to or greater than the contributions required of the employee by the organization. However, these judgements are affected by both the individuals desire to leave the organization and the ease with which he or she could depart. Clearly, turnover is a complex process. That is, although some individual employees may quit a job on impulse, most people who leave spend time initially evaluating their current job against possible alternatives, developing intentions about what to do and engaging in various types of job search behavior.

The cost of losing a high performing employee who has a high degree of knowledge, skills and abilities or an employee who is employed in an area where there is a labour market shortage can be substantial to the organization's performance, productivity and service delivery (Swinney, 1987). In addition, turnover can have a negative impact on other employees by disrupting group socialization processes and increasing internal conflict, which can lead to triggering additional turnover (North and Finlayson, 2005). Studies have shown that cost related to directly replacing an employee can be as high as $50-60 \%$ of the employee's annual salary. But the total cost of turnover can reach as high as $90-200 \%$ of employee's annual salary. These costs include candidate interviews, new hire training, the recruiter's salary, separation processing, job errors, lost sales, reduced morale and a number of other costs to the organization (Swinney, 1987). Kokemuller (2006) opines that unplanned and frequent employee turnover is generally regarded as bad for an organization. High employee turnover rates typically mean organizations are doing 
a poor job of selecting the right employees, failing to provide a motivating work environment or losing out to employers that offer better pay and benefits.

Mushrush (2014) states that an organization must measure the cost of turnover, develop retention strategies and plan for some expected turnover and a changing workforce culture. Employers must recognize that quality of work life is becoming more and more important to employees. To guard against high rate of employee turnover, organizations should undertake the following:

- Hire the right caliber of people

- Undertake continual career development to enhance employees' performance

- Provide conducive working environment with the requisite resources to enhance productivity

- Put in place adequate compensation packages to motivate and boost the morale of employees

- Recognize employee accomplishments and reward them accordingly

- Promote inter and intra personal engagements in the workplace to ensure collective decision making process

- Put in place appropriate retirement benefits to guarantee employees' comfort during old age and any incapacities, etc.

In sum, while the organization is production/service delivery oriented, it must at the same time be employee friendly to reduce to the barest minimum employee turnover in the organization.

\section{Methodology}

\subsection{Research Design}

The descriptive survey design was employed to collect data. A survey design provides a description of trends, attitudes or opinions of population by studying a sample of that population. In this study, data was collected through the administration of questionnaire and interview guide (Creswell, 2003; Fraenkel and Wallen, 2008; Seidu, 2012).

\subsection{Population}

The population of the study consisted of all the administrative and teaching staff of the Perez University College in Winneba, Central Region of Ghana. The target population was 70 people.

\subsection{Sample and Sampling Procedure}

A sample consists of individuals, objects or events that form part of the population (Creswell, 2003; Fraenkel and Wallen, 2008; Seidu, 2012). In collecting data for the study, the researcher contacted various departments, units and sections of the institution. The convenience sampling technique was used to collect a sample of sixty (60) respondents to form the sample size. A convenience sample is a group of individuals who are available for a study. The researcher chose the convenience sampling technique because of the difficulty of getting individuals to participate in the study.

\begin{tabular}{l|l}
\multicolumn{2}{c}{ Table-1. Category of Respondents and Sample $(\mathrm{N}=60)$} \\
\hline Respondents & $\mathbf{N}$ \\
\hline Administrative staff & 20 \\
\hline Teaching Staff & 40 \\
\hline Total & 60 \\
\hline Source: Field data, 2016 & \\
Key to Table 1 N = Sample Size &
\end{tabular}

\subsection{Study Instruments}

The researcher designed a questionnaire for the study. The questionnaire was made up of close ended questions such as checklist and the likert-type questions as well as open-ended questions. The questionnaire was filled by all the sixty respondents. However, the Principal and the Heads of departments were interviewed in addition to answering the questionnaire. This was done to obtain in-depth information on the issues of staff attrition in the College. Structured interview guide was also developed for the respondents, specifically the various head of departments, units and sections. The content and face validity of the instruments were done by fellow researchers at the Centre for Educational Policy Studies, Institute for Educational Research and Innovation Studies of the University of Education, Winneba and their comments included in the final questionnaire and interview schedules. The pre-testing of the study instruments were carried out in the Ashesi University College in Accra. The reliability of the study instruments was computed by using the Cronbach co-efficient alpha (i. e. alpha $=.56$ ). This is mathematically written as $a=0.6856$ and falls within accepted range of 0.500 and 1.000 (Creswell, 2003).

\section{Findings and Discussions}

The first research question was what causes staff turnover in private universities in Ghana? The study identifies the following as causes of staff turnover in private universities. These are low salary levels, inadequate working tools, absence of well stocked library, lack of recognition/promotion, heavy workload, lack of staff development opportunities, victimization of employees, absence of job security, poor retirement benefits etc. Table 2 shows the responses of respondents to the causes of staff turnover in private universities. 
Table-2. Causes of Staff Turnover $(\mathrm{N}=60)$

\begin{tabular}{l|l|l|l|l|l|l|l|l}
\hline Cause & \multicolumn{2}{|l|}{ Responses } & & & & & \\
\hline & SA & A & U & DA & SDA & WM & STD & I \\
\hline Low salary levels & 18 & 30 & 2 & 6 & 4 & 3.8 & 1.9 & U \\
\hline Inadequate working tools & 15 & 25 & 5 & 10 & 5 & 3.5 & 1.8 & U \\
\hline Absence of well-stocked & & & & & & & & \\
\hline Library & 7 & 10 & 3 & 25 & 15 & 2.4 & 1.5 & DA \\
\hline Lack of recognition/ & & & & & & & & \\
\hline Promotion & 30 & 20 & 1 & 5 & 4 & 4.1. & 2.0 & $\mathrm{~A}$ \\
\hline Heavy workload & 3 & 10 & 2 & 28 & 17 & 2.2 & 1.4 & DA \\
\hline Lack of staff development & & & & & & & & \\
\hline Opportunities & 28 & 32 & 2 & 2 & 2 & 4.2 & 2.0 & $\mathrm{~A}$ \\
\hline Victimisation of employees & 28 & 33 & 1 & 1 & 0 & 4.4 & 2.1 & $\mathrm{~A}$ \\
\hline Absence of job security & 21 & 30 & 0 & 4 & 2 & 4.1 & 2.0 & $\mathrm{~A}$ \\
\hline Poor retirement benefits & 19 & 26 & 2 & 5 & 2 & 4.0 & 2.0 & $\mathrm{~A}$ \\
\hline
\end{tabular}

Mean of means $=3.6$ Standard deviation $=1.8$

Source: Fieldwork (2016)

Key to Table

$\mathrm{N}=$ Sample Size

$\mathrm{SA}=$ Strongly Agree

$\mathrm{A}=$ Agree

$\mathrm{U}=$ Uncertain

$\mathrm{DA}=$ Disagree

SDA $=$ Strongly Disagree

$\mathrm{WM}=$ Weighted Mean

$\mathrm{SD}=$ Standard Deviation

$\mathrm{I}=$ Interpretation

\subsection{Interpretation of Weighted Mean}

$5.0=$ Strongly Agree, $4.0-4.9=$ Agree, $3.0-3.9=$ Uncertain, $2.0-2.9=$ Disagree and $1.0-1.9=$ Strongly Disagree.

Table 2 indicates a mean of means of 3.6 and a standard deviation of 1.8. This means that respondents generally agreed that high staff turnover in private universities is caused by multiple of factors as indicated in the table. This agrees with Mankoe (2007); Afenyo (2012); Allen (2006) when they asserted that in organizations where compensations are low, career progression is negligible and job security cannot be assured, employee turnover is high. In an interview with one of the lecturers in the University where the survey took place, this is what he said:

We receive low compensation for the strenuous work we do. Our libraries are not well

stocked with current publications which negatively affect teaching, learning and research. Coupled with administrative high handedness, absence of staff development opportunities and career progression, lack of job security as well as poor retirement benefits, staff attrition becomes the order of the day.

The interview response indicates that employee turnover in private universities is a reality and a challenge in these institutions. Staff leaves in their numbers for employment elsewhere. The implication is that staffs are not satisfied with the conditions of service as well as the state of facilities that support teaching and learning and research in the College. This also implies scarcity of qualified staff especially lecturers in the institution.

The second research question was on what constitutes compensation package for employees? The study identifies the following as compensation package for employees. They are as follows: salaries, promotion, accommodation, annual leave benefits, and scholarships for employees' children, free healthcare and safety measures, free meals, retirement benefits etc.

Table 3 indicates the responses of respondents to the compensation package for employees in private universities.

Table-3. Compensation Packages for Staff $(\mathrm{N}=60)$

\begin{tabular}{l|l|l|l|l|l|l|l|l}
\hline Compensation Packages & \multicolumn{2}{|l|}{ Responses } & & & & & \\
\hline & SA & A & U & DA & SDA & WM & STD & I \\
\hline Salaries & 28 & 30 & 1 & 1 & 0 & 4.4 & 2.1 & $\mathrm{~A}$ \\
\hline Promotion & 21 & 34 & 1 & 2 & 2 & 4.1 & 2.0 & $\mathrm{~A}$ \\
\hline Accommodation & 26 & 28 & 2 & 3 & 1 & 4.2 & 2.0 & $\mathrm{~A}$ \\
\hline Annual leave benefits & 20 & 35 & 1 & 2 & 2 & 4.1 & 2.0 & $\mathrm{~A}$ \\
\hline Scholarships for employees' & & & & & & & & \\
\hline Children & 24 & 31 & 1 & 3 & 1 & 4.2 & 2.0 & $\mathrm{~A}$ \\
\hline Free healthcare and safety & & & & & & & & \\
\hline Measures & 27 & 29 & 0 & 2 & 2 & 4.2 & 2.0 & $\mathrm{~A}$ \\
\hline Meals & 32 & 23 & 1 & 3 & 1 & 4.3 & 2.1 & $\mathrm{~A}$ \\
\hline Retirement Benefits & 25 & 31 & 0 & 2 & 2 & 4.2 & 2.0 & $\mathrm{~A}$ \\
\hline
\end{tabular}

Mean of means $=4.2 \quad$ Standard Deviation $=2.0$

Source: Fieldwork, 2016

Table 3 shows a means of mean of 4.2 and a standard deviation of 2.0. This means that there are compensation packages for staff of private universities. Mankoe agrees to the compensation packages in the universities. He, 
however, opines that there are variations in terms of the monetary value put on the compensation packages in various private universities. In an interview with the principal of the University, this is what he said with regards to the compensation packages.

"In order to maintain our employees in our organization, we have put in place the following compensation packages to induce our employees especially the academic staff (i. e. lecturers) towards high productivity in teaching, learning and research output. These are the packages:

- Improved salary scales

- Enhanced promotion prospects

- Subsidized accommodation

- Annual leave allowance

- Scholarships for employees'

Children below age 18 years

- Free medical care

- Monthly allowance for meals

- Enhanceds retirement benefits for staff etc

In another interview with one of the lecturers on compensation packages for them, this is what he said:

"Our salary scales are low as compared with our counterparts with similar qualifications in public universities. Indeed, staff development towards professionalism and career progression is almost negligible. There is virtually no guarantee for job security. An employee can be fired at will due to administrative highhandedness. We work at the mercy of the proprietor of the organization. There is also no clear cut policy on retirement plans and benefits".

It can be deduced from the interview responses that there are compensation packages for staff in private universities; nevertheless, employees are not satisfied with what is offered by their employers. Since staff are not satisfied with the compensation packages offered by the College, they leave at the least opportunity, which adversely affect teaching, learning and research in the institution.

The third research question was on how does staff turnover influence teaching, learning and research? The study identifies the following as influence of staff turnover on teaching, learning and research. These are as follows: poor quality teaching, low research output, high lecturer- student ratio, non-mentoring of new lecturers, poor learning outcomes, absence of staff development programmes, no team research among lecturers, frequent disruption of lectures etc.

Table 4 indicates the responses of respondents to the influence of staff turnover on teaching and research.

Table-4. Influence of Staff Turnover on Teaching, Learning and Research in Private Universities (N=60)

\begin{tabular}{l|l|l|l|l|l|l|l|l}
\hline Staff Turnover Impact & \multicolumn{2}{l}{ Responses } & & & & \\
\hline & SA & A & Uncertain & DA & SDA & WM & SD & I \\
\hline Poor quality teaching & 34 & 20 & 1 & 3 & 2 & 4.3 & 2.1 & A \\
\hline Low research output & 24 & 30 & 2 & 3 & 1 & 4.2 & 2.0 & $\mathrm{~A}$ \\
\hline High lecturer-student ratio & 35 & 20 & 1 & 3 & 1 & 4.4 & 2.1 & $\mathrm{~A}$ \\
\hline Non-mentoring of new & & & & & & & & \\
\hline Lecturers & 11 & 13 & 2 & 20 & 14 & 2.8 & 1.7 & DA \\
\hline Low lecturer-student & & & & & & & & \\
\hline Interaction & 26 & 29 & 1 & 3 & 1 & 4.3 & 2.1 & $\mathrm{~A}$ \\
\hline Unqualified lecturers & 23 & 32 & 0 & 3 & 2 & 4.1 & 2.0 & $\mathrm{~A}$ \\
\hline Poor learning outcomes & 25 & 30 & 1 & 3 & 1 & 4.3 & 2.1 & $\mathrm{~A}$ \\
\hline Non-staff development & & & & & & & & \\
\hline Programmes & 23 & 29 & 0 & 2 & 2 & 4.3 & 2.1 & $\mathrm{~A}$ \\
\hline No team research among & & & & & & & & \\
\hline Lecturers & 23 & 33 & 0 & 3 & 1 & 4.2 & 2.1 & $\mathrm{~A}$ \\
\hline Frequent disruption of Lectures, etc & 25 & 31 & 1 & 2 & 1 & 4.3 & 2.1 & $\mathrm{~A}$ \\
\hline Mean of means = Standard deviation & 2.0 & & & & &
\end{tabular}

Table 4 indicates a mean of means 4.1 and a standard deviation of 2.0. This means that staff turnover has strong influence on teaching, learning and research in private universities. This influence, negatively affects the quality of products from private universities in terms of academic excellence. This finding agrees with Kidwell and Bennet (2014); Coetzee and Rothman (2002) when they said that academics are essential to the quality of graduates from the universities. Therefore, their reduced number or absence seriously affects on the quality of teaching, learning and research in tertiary educational institutions.

In an interface with the Principal of the University where the survey was conducted, this is what he said with regard to staff attrition and its influence on teaching, learning and research.

Although we are doing our best to motivate our staff to stay on the job, especially the lecturers, nevertheless, staff turnover among the teaching staff is very high. Its seriously affects teaching, learning and research as well as the committee system because it is the lecturers who serve the various committees as part of the administrative machinery of the university. It should be admitted that the reduced number or absence of lecturers negatively affects the quality of graduates in private universities. There is also frequent disruption of scheduled lectures due to scarcity of lecturers. In the process, we make do with less qualified lecturers.

Indeed, staff turnover of top administrators and lecturers is

a challenge that needed to be addressed. said:

In another interface with a group of both top administrators and lecturers on the same issue, this is what they 
Staff turnover among top administrators and lecturers is a reality in private universities mainly because of poor conditions of service and administrative high handedness. There is also paucity of library resources, accommodation for staff as well as other related issues that impinge on the work of administrators and lecturers. There is also the added problem of academic quality of students admitted.

It is deduced from the interactions with the principal and the group of both administrators and lecturers that staff attrition negatively impacts on teaching, learning, research and governance in private universities. It also implies that private universities do not have the required number of lecturers and administrators in terms of quantity and quality to teach, research and manage the institutions. Their library facilities are poor and lack internet connectivity to promote effective teaching, learning and research. The students admitted are generally those who could not meet the entry requirements of public universities. This suggests that the academic quality of their students is poor, and this seriously affects learning outcomes and quality of the products of private universities in Ghana.

\section{Conclusion}

The liberalization of tertiary education in Ghana has led to the establishment of private universities alongside the public universities in the provision of tertiary education. Staff turnover in private universities is high due to low compensation for top administrators and lecturers. On the average, about 54\% lecturers and administrators leave every academic year for employment elsewhere. Staff attrition in these institutions has resulted in low quality in teaching, learning and research as well as efficiency in management and governance. It is suggested that stakeholders in private universities establish endowment fund which can be used to improve compensation packages for lecturers and other staff members.

Many of the lecturers $(75 \%)$ lack advanced or terminal degree qualifications. This implies that quality lecture delivery and research is adversely affected. It further suggested that such an endowment fund could be used to support students' post-graduate studies as well as staff development for lecturers and administrators to pursue advanced or terminal degrees.

Library resources are poor in quality and quantity and information, communication and technology (ICT) connectivity is low to support effective teaching, learning and research. This implies that the quality of their library resources is low and does not enhance quality academic work which also seriously affects the quality of the products from the private universities in Ghana. Private universities could also solicit support from other educational stakeholders such as Ghana Book Trust, the government of Ghana and donor agencies.

\section{Recommendations}

The following recommendations are made to reduce to the barest minimum staff turnover and also to strengthen teaching, learning, research and management/governance in private universities in Ghana.

1. In order to sustain staff retention in private universities in Ghana especially among lecturers and administrators, stakeholders should improve conditions of service.

2. Staff development programmes should be prioritized by management of private universities to assist lecturers and administrators to obtain advanced and terminal degree qualifications to improve teaching, learning and research

3. Management of private universities should establish research fund to motivate lecturers undertake both individual and team research in order to increase research output.

4. Management of private universities need to take steps to provide the needed Library materials in private universities in order to ensure that they are well-stocked with current publications together with ICT connectivity to support teaching, learning and research.

5. Administration and management of private universities should be open, transparent, fair and objective devoid of nepotism, favoritism and partisan cleavages. The governing councils and management should take responsibility to address this situation.

6. Governing councils and management of private universities should state the terms of conditions of employment to successful applicants in clear language and job security should be guaranteed.

7. Management of private universities should assist lecturers as well as other staff of private universities with accommodation to motivate them to work.

\section{References}

Abelson, M.A. and B.O. Baysinger, 1984. Optimal and dysfunctional turnover toward an organizational level model. Academy of Management Review, 9(2): $331-341$

Adu, K.H., 2009. Private higher education on the rise. Retrieved from http://www.universityworldnews.com/.

Afenyo, S.K., 2012. The effect of motivation on retention of workers in the private sector. A case study of Zoomlion Company, Ghana Limited. Unpublished M.A. Thesis, KNUST, Kumasi

Allen, G.D., 2006. Retaining talent: A guide to analyzing and managing employee turnover. Retrieved from http://www.shrm.org.

Buckingham, M. and C. Coffman, 1999. First break all the rules: What the world's greatest managers do differently. New York: Simon \& Shuster.

Byars, L. and L. Rue, 2006. Human resource management. 8th Edn., New York: McGraw Hill Inc.

Cascio, W.F., 1982. Managing human resources. New York: McGraw Hill Inc.

Coetzee, M. and S. Rothman, 2002. An adapted model of burnout for employers at a higher education institution in South Africa. South African Journal of Industrial Psychology, 30(3): 29 - 40

Creswell, J.W., 2003. Research design: Qualitative and quantitative approach. Thousand Oaks. CA: Sage Publication.

Fraenkel, J.R. and N.E. Wallen, 2008. How to design and evaluate research in education. New York: McGraw Hill, Inc.

Ganesan, S., 2010. Job satisfaction and turnover intention among private sector employees in Kedah, Malaysia. MA Dissertation. Malaysia. University of Utara.

Heathfield, G.K., 2011. Effects of pre-interview beliefs on applicant's reactions to campuus interviews. Academy of Management Jouurnal, 40(4): 947-966.

Hillmer, M.A., 2004. The real costs of turnover: Lessons from a center. Human Resource Planning, 27(13): 34 - 41 
Kidwell, R.E. and N. Bennet, 2014. Employee propensity to withhold effort. A conceptual model to interest three avenues of research. Academy of Management Review, 18(3): $423-456$.

Kidwell, R.E. and N. Bennet, 2014. Employee propensity to withhold effort. A conceptual model to intersect three avenues of research. Academy of Management Review, 18(3): 423 - 456.

Kokemuller, N., 2006. Negative effects of turnover. Feature Article for Houston Chronicle. Texas. Available from http//instaad.net.

Lee, F.H. and F.Z. Lee, 2007. The relationship between HRM practices, leadership style, competitive strategy and business performance in Taiwanese steel industry: $953-971$ Retrieved from http//www.sciencedirect.

Mankoe, J.O., 2007. Educational administration and management in Ghana. 2nd Edn., Kumasi: Payless Limited.

Martin, A. and G. Roodt, 2008. Perceptions of organizational commitment, job satisfaction and turnover intentions in a post-merger South African tertiary institution. South African Journal of Industrial Psychology, 34(1): 23 - 31.

Mushrush, W., 2014. Reducing employee turnover. Columbia Bialaffere Hall. Retrieved from http://www.missouribusiness.net.

Netswera, 2006. Employee retention factors for South Africa higher eduucation instituutions: A case study. South African Journal of Human Resource Management, 3(2): 36-40.

Ng, T., 2014. Toward a further understanding of the relationship between perceptions of support and work attitudes - a meta-analysis. Group and Organization Management, 33(2): $243-268$

North, N. and M. Finlayson, 2005. Turnover among nurses in New Zealand's district heath boards: A national survey of nursing tuurnover costs. New Zealand Journal of Employmment Relations, 30(10): 49-63.

Rossano, E., 1985. Factors associated with the turnover intentions of Ohio co-operative extension country agents. Unpublished Doctoral Thesis. Columbus: The Ohio State University.

Seidu, A., 2012. Research method for educational administration and management students. Kumasi: Payless Limited.

Shikha, V.G., 2012. Talent acquisition and retention issues of facility in higher education. Journal of Human Resource Management and Development, 2(2): $20-31$.

Stavrou-Costea, E., 2005. Flexible work bundles and organizational competitiveness in Europe: Towards a framework. Journal of Organizational Behaviour, 26(12): $6-10$.

Swinney, D.A., 1987. Prosody and the development of comprehension. Journal of Child Language, 14(9): $145-167$. 